RACAR : Revue d'art canadienne

Canadian Art Review

\title{
From Great-Grandmothers to Great-Granddaughters: "Moving Life" in Baby Carriers and Birchbark Baskets
}

\section{Alexandra Kahsenni:io Nahwegahbow}

Volume 42, numéro 2, 2017

Continuities Between Eras: Indigenous Art Histories

Continuité entre les époques : histoires des arts autochtones

URI : https://id.erudit.org/iderudit/1042949ar

DOI : https://doi.org/10.7202/1042949ar

Aller au sommaire du numéro

\section{Éditeur(s)}

UAAC-AAUC (University Art Association of Canada | Association d'art des universités du Canada)

ISSN

0315-9906 (imprimé)

1918-4778 (numérique)

Découvrir la revue

Citer cet article

Nahwegahbow, A. K. (2017). From Great-Grandmothers to

Great-Granddaughters: "Moving Life" in Baby Carriers and Birchbark Baskets.

RACAR : Revue d'art canadienne / Canadian Art Review, 42(2), 100-107.

https://doi.org/10.7202/1042949ar

\section{Résumé de l'article}

Les porte-bébés et les paniers d'écorce autochtones sont, en tant que réceptacles, conçus pour porter et tenir. Outre cette fonction, ils sont aussi détenteurs d'histoires, de mémoire, et de liens familiaux. Créés individuellement et ornementés avec soin, ces objets constituent une sorte de portrait des femmes qui les ont produits, ainsi que des générations qui ont hérité des pratiques et des motifs servant à les fabriquer. En élargissant la définition de la notion de portrait de famille, cet article considère deux objets provenant de Bear Island, en Ontario. Le premier est un porte-bébé ayant appartenu à Madeline Katt Theriault, et le deuxième est un panier d'écorce vraisemblablement créé par son arrière-grand-mère Angele Katt. Par leur parenté, ces réceptacles englobent une histoire multigénérationnelle qui s'étend de l'arrière-grand-mère à son arrière-petite-fille.
Tous droits réservés (C) UAAC-AAUC (University Art Association of Canada | Association d'art des universités du Canada), 2017
Ce document est protégé par la loi sur le droit d'auteur. L’utilisation des services d'Érudit (y compris la reproduction) est assujettie à sa politique d'utilisation que vous pouvez consulter en ligne.

https://apropos.erudit.org/fr/usagers/politique-dutilisation/ 


\title{
From Great-Grandmothers to Great-Granddaughters: "Moving Life" in Baby Carriers and Birchbark Baskets
}

\author{
Alexandra Kahsenni:io Nahwegahbow
}

\begin{abstract}
Les porte-bébés et les paniers d'écorce autochtones sont, en tant que réceptacles, conçus pour porter et tenir. Outre cette fonction, ils sont aussi détenteurs d'histoires, de mémoire, et de liens familiaux. Créés individuellement et ornementés avec soin, ces objets constituent une sorte de portrait des femmes qui les ont produits, ainsi que des générations qui ont hérité des pratiques et des motifs servant à les fabriquer. En élargissant la définition de la notion de portrait de famille, cet article considère deux objets provenant de Bear Island, en Ontario. Le premier est un porte-bébé ayant appartenu à Madeline Katt Theriault, et le deuxième est un panier d'écorce vraisemblablement créé par son arrière-grand-mère Angele Katt. Par leur parenté, ces réceptacles englobent une histoire multigénérationnelle qui s'étend de l'arrière-grand-mère à son arrière-petite-fille.
\end{abstract}

Alexandra Kahsenni:io Nahwegahbow is a PhD Candidate in Cultural Mediations at Carleton University

-alexandra.nahwegahbow@ carleton.ca

1. Anishinaabe means "first" or "original peoples." Other translations of the word include "the good people" or "the spontaneous beings." Although there are variations in its spelling, this is the word used by the Ojibwe, Chippewa, Odawa,

Potawatomi, Nipissing, Mississauga, and Algonquin nations.

2. Basil Johnston, Ojibway Heritage (Toronto: McClelland \& Steward Limited, 1976), 21.

3. Ibid., 109; and Michael D. McNally, Honoring Elders: Aging, Authority, and Ojibwe Religion (New York: Columbia University Press, 2009), 57.

\section{Aniish Ezhi Bimaadiziyin?}

This old Anishinaabe ${ }^{1}$ greeting, which is generally understood to mean, "Hey, how's it going?," may be literally translated as, "How are you living?," or "How is your life?" As my Anishinaabemowin teacher Jeff Monague jokingly says, "It is a question that you better make sure you have the time for before you ask, because you could be listening for a while." Indeed, in Anishinaabe epistemologies, the concept of life and living, or more specifically minobimaadiziwin-living "the good life"-is a complex one. Viewed through a holistic understanding of health and wellness, "the good life" fosters balanced physical, emotional, mental, and spiritual states of being. This understanding of life is often conceived as being circular and oriented to the four cardinal directions. These four quadrants are necessarily intertwined-they comprise life and one whole existence; anything less and life and being become incomplete and unintelligible. ${ }^{2}$ In keeping with this understanding, many Anishinaabek have metaphorically described the natural rhythms of the path of life as a spatial passage over four hills. ${ }^{3}$ According to Anishinaabe storyteller Basil Johnston, these hills of life correspond to different physical and moral stages: infancy and childhood (a time of preparation), youth (a time of quest), adulthood (a time of vision), and old age (a time of fulfillment). ${ }^{4}$

Applying this culturally based narrative framework to a study of material culture is consistent with current leading Indigenous scholarship surrounding holistic health and well-being. ${ }^{5}$ This approach allows for a more comprehensive examination of the wider expressive potential of Anishinaabe-made objects, and is grounded in distinctive cultural understandings. Using this narrative structure to frame the intergenerational exchange of knowledge between mothers and daughters, as well as grandmothers and granddaughters, makes clear the ways in which these four stages are deeply linked. In the early twentieth century, the Anishinaabek of Wasauksing First Nation (Parry Island, Ontario) told the anthropologist Diamond Jenness about the concept of madjimadzuin-the "moving life-line" or "moving life"-in which women play a central role. The Wasauksing Anishinaabek likened their life-lines and ancestral kin to the stars and celestial bodies in the night sky:

The Milky Way... is an enormous bucket-handle that holds the earth in place; if it ever breaks the world will come to an end. The "life-line" is a human Milky Way; it is the chain of ancestors connecting those who have gone before with those who follow, the line of ancestors and descendants together with all the inheritance factors they carry with them. ${ }^{6}$ 
4. Kim Anderson, Life Stages and Native Women: Memory, Teachings, and Story Medicine (Winnipeg: University of Manitoba Press, 2011), 7; and Johnston, Ojibway Heritage, 120.

5. See Anderson, LifeStages.

6. Diamond Jenness, The Ojibwa Indians of Parry Island, Their Social and Re ligious Life (Ottawa: National Museum of Canada, 1935), 90.

7. Ibid.

8. Johnston, Ojibway Heritage, 117.

9. n’Daki Menan means “our land," the traditional territory of the Teme-Augama Anishinabai, or "the deep water people," which surrounds Lake Temagami, Ontario.

10. Renee Elizabeth Mzinegiizhigo-kwe Bedard, "An Anishinaabe-kwe Ideology on Mothering and Motherhood," in "Until Our Hearts are on the Ground" : Aboriginal Mothering, Oppression, Resistance and Rebirth, eds.

D. Memee Lavell-Harvard and Jeannette Corbiere Lavell (Toronto: Demeter Press, 2006), 66.

11. Madeline Katt Theriault, Moose to Moccasins: The Story of Ka Kita Wa Pa No Kwe (1st ed, 1992; Toronto: Dundurn Press, 2006), 29.

12. Marie Battiste, "Indigenous Knowledge and Pedagogy in First $\mathrm{Na}$ tions Education: A Literature Review with Recommendations" (prepared for the National Working Group on Education and the Minister of Indian and Northern Affairs Canada, Ottawa October 31, 2002), 15.

13. Laura Peers and Jennifer S. H. Brown, "'There is no End to Relationship Among the Indians': Ojibwa Families and Kinship in Historical Perspective," The History of the Family, 4, 4(1999): 529-555.

14. See Peter Grant, "The Saulteaux Indians about 1804," in Les bourgeois de la Compagnie du Nord-Ouest, ed. Louis Rodrigue Masson, vol. 2 Quebec: Impr. générale A. Coté et cie) 322-323; John Long, Voyages and Travels of an Indian Interpreter (London: Robsen, 1791), 60-61; William Wentworth- Fitzwilliam, The NorthWest Passage By Land (London: Cassell, Petter and Galpin, 1865), 85; Frances Densmore, "Chippewa Customs," Bureau of American Ethnology, Bulletin 86 (Washington: Smithsonian Instititions, 1929), 48-50; Sister Mary Inez Hilger, Chippewa Child Life and Its Cultural Background (1951; repr. St. Paul: Minnesota Historical Society Press, 1992), 21-25.

15. Johann Georg Kohl, KitchiGami: Wanderings Around Lake Superior (London: Chapman and Hall, 1860), 7 .

16. Anishinabekwek is the plural of Anishinaabekwe, which means "Anishinaabe woman."
As bearers, carriers, and primary caregivers to future generations, women were considered to be guardians responsible for maintaining this netted chain of "moving life."

It is through the story of Madeline Katt Theriault-an Anishinaabe woman whose autobiography Moose to Moccasins (1992) and very special family treasures are now housed in the Royal Ontario Museum-that we can begin to understand the rhythms of the four life stages, as well as the significant roles women play in the continuity of the life-line. For, as Basil Johnston writes on the holistic understanding of bimaadziwin (life), "There is continuity, there is no break." 8

Named Ka Kita Wa Pa No Kwe, which means "Wise Day Woman," Madeline was born and delivered by a midwife in a tent in n'Daki Menan, ${ }^{9}$ Bear Island, Lake Temagami, Ontario, in 1908. In her first years, Madeline and her mother Elizabeth Petrant, lived with her mother's grandparents Angele and Michel Katt Sr. When Madeline reached the age of two, her great-grandmother began raising her, as her mother could no longer do so. This custom of kinship adoption was and is still very common in many Indigenous communities, as the work of mothering is not biologically defined. Childcare was understood as collective work, and the roles of mothers, aunties, grannies, and adoptive mothers were often viewed as fluid and interchangeable. ${ }^{10}$

As a child, Madeline spent a great deal of time with her great-grandmother, and fondly remembers her daily teachings about living on the land and how to interpret her surroundings. Madeline describes her great-grandmother as a central source of strength, whose knowledge helped "set her path in life." And so, her journey began on the first incline of the Four Hills: infancy and childhood-the time of preparation.

This early stage of life involves being nurtured, depending on others, and developing trust. It is also a time of immense learning, which occurs through the sensory experiences of listening, observing, and feeling the rhythms of daily life in the surrounding community. According to Marie Battiste, Indigenous pedagogy values a person's ability to learn independently by observing, listening, and participating with minimal interference or direct instruction. ${ }^{12}$ This method of knowledge transfer is embodied in the design and daily use of the tikinaagan, or cradleboard. Lovingly crafted by family and community members in order to welcome a new life, the creation of the tikinaagan followed the traditional, complementary division of labour between men and women: the father or grandfather carved the wooden backboard, footrest, and hoop, while the mother or grandmother fashioned the hide or fabric covering. ${ }^{13}$

The tikinaagan has often been praised for its clever design, as well as the physical safety it afforded infants. ${ }^{14}$ In the first place, it was highly mobile and allowed a mother to have her baby constantly with her or under her watchful eye; in the second, the sophisticated addition of the curved hoop protected the baby's face should the carrier ever fall forward. ${ }^{15}$ This paper will focus, however, on the way the tikinaagan embodies a place of conceptual protection for young people. Many Anishinabekwek ${ }^{16}$ have drawn a comparison between the swaddling of the cradleboard wrappings and the womb. Indeed, an Anishinaabekwe from Miskwaagamiiwi-zaaga'igan (Red Lake Reservation, 
17. Sister Mary Inez Hilger, Chippewa Child Life and its Cultural Background (Washington: Government Print Office, 1951), 24.

18. David Penney, "Great Lakes Indian Art: An Introduction," in Great Lakes Indian Art, ed. David Penney (Detroit: Wayne State University Press, 1989), 11.

19. Frances Densmore, Chippewa Customs, 107; and Cath Oberholtzer, "Net Baby Charms: Metaphors of Protection and Provision," in Papers of the Twenty-Fourth Algonquian Conference, ed. William Cowan (Ottawa: Carleton University, 1993), 318.

20. Anderson, Lifestages, 95

21. Ruth B. Phillips, "Aboriginal Modernities: First Nations Art, c.1880-1970," in The Visual Arts in Canada:The Twentieth Century, eds. Anne Whitelaw, Brian Foss, and Sandra Paikowski (Oxford: University of Oxford Press, 2010), 358.

22. Liza Mosher, "We Have Gone Back to the Original Teachings," in In the Words of Elders: Aboriginal Cultures in Transition, eds. Peter Kulchyski, Don McCaskill, and David Newhouse (Toronto: University of Toronto Press, 1999), 141165; Anderson, Life Stages, 9.

23. Ruth B. Phillips, "Materiality and Cultural Translation: Indigenous Arts, Colonial Exchange and Postcolonial Perspectives," in Cultural Histories of the Material World, ed. Peter N. Miller (New York: Bard Graduate Centre, 2010), 81.
Minnesota) once told anthropologist Sister Mary Inez Hilger, "You know, I used to hear my old grandmother say that babies like best to be wrapped tightly in deer hide for then they feel like they did in their mother's womb." ${ }^{17}$ Seen as an extension of a person's first environment in their mother's body, the tikinaagan is associated with warmth and utmost security.

In this first stage of life, developing trust and feelings of safety and belonging are critical, as the time of infancy is considered very precarious. It is believed that children and young people are nearer to the spirit world than their adult counterparts, because they only recently made their journey to this realm. Despite seeming passive, their souls are quite active and they may easily slip back into the spirit world. It is for this reason that many Anishinaabe mothers carefully adorned the coverings of their child's cradleboards with powerful beaded or painted designs, which served to protect and offer security to the baby wrapped within. ${ }^{18}$ Various objects were also hung from the curved bow to ward off any bad spirits or dreams that might bring about restlessness. ${ }^{19}$ In nurturing an infant's feeling of safety through the thoughtful ornamentation of their cradle, mothers and grandmothers conveyed the value of the child's place within the family, community, and madjimadzuin-the moving life-line.

In revisiting Madeline's autobiography, which is accompanied by a number of personal family photographs, readers witness her journey along the Four Hills: first, as a young infant swaddled in her cradleboard, which was lovingly designed by several family members; and second, as a youth on the next hill of life, where one is meant to learn and practice independence, discipline, and responsibility. According to Kim Anderson, it is at this age that all community members begin to have a hand in ensuring that you learn what you need to know. ${ }^{20}$

In Moose to Moccassins, Madeline recounts her memories of being a young person, and the many times she listened attentively to her great-grandmother, watching her hands as she expertly wove rabbit-skin blankets, tanned and smoked moose hides, sewed snowshoes, and formed sheets of birchbark into beautiful containers. ${ }^{21}$ These careful teachings-a transgenerational transmission of knowledge-guided and prepared Madeline as she traversed the third hill of adulthood, where she, in turn, took on the role of teacher and life-line guardian as the carrier of her own children-what has been referred to as "the planting life." 22

The hill of adulthood is a time of responsibility and reciprocity. You are to provide and return the care that family and community members showed you as a young person. When Madeline reaches this planting stage and begins to raise her own children, her grandfather Michel Katt Jr. carefully crafts a wooden cradleboard and assembles it with a fine beaded front cover, made by Madeline's mother Elizabeth before she passed in 1919.

In many ways, this cradleboard, | fig. 1 | which Madeline donated to the Royal Ontario Museum in Toronto at the end of her life, ${ }^{23}$ embodies what the Wasauksing Anishinaabek referred to as madjimadzuin-the human Milky Way, or moving life. In tenderly adorning the cradleboard cover with floral beadwork just a few short years before she passed, Madeline's mother Elizabeth was preparing her future grandchildren for their entrance into 
Figure 1. Cradleboard and mossbag, 1919-1938, wood,

cotton cloth, glass beads, metal; Elizabeth Katt Petrant and Michel Katt Jr., Anishinaabe (Ojibwe), Temagami, oN. Collection of the

Royal Ontario Museum 998.134.3.1 (C) ROM.
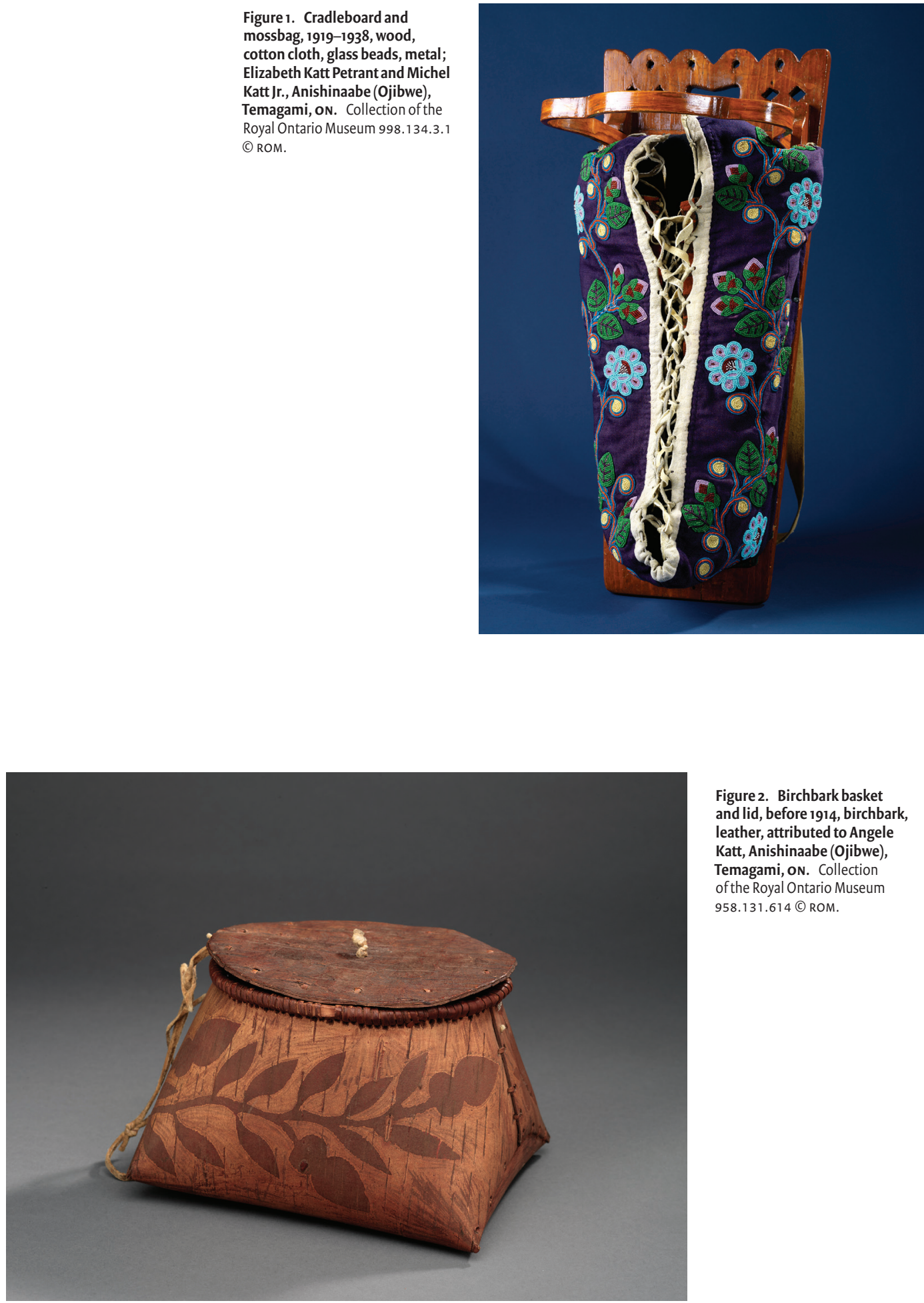

Figure 2. Birchbark basket and lid, before 1914, birchbark, leather, attributed to Angele Katt, Anishinaabe (Ojibwe), Temagami, oN. Collection of the Royal Ontario Museum 958.131.614 @ ROM. 


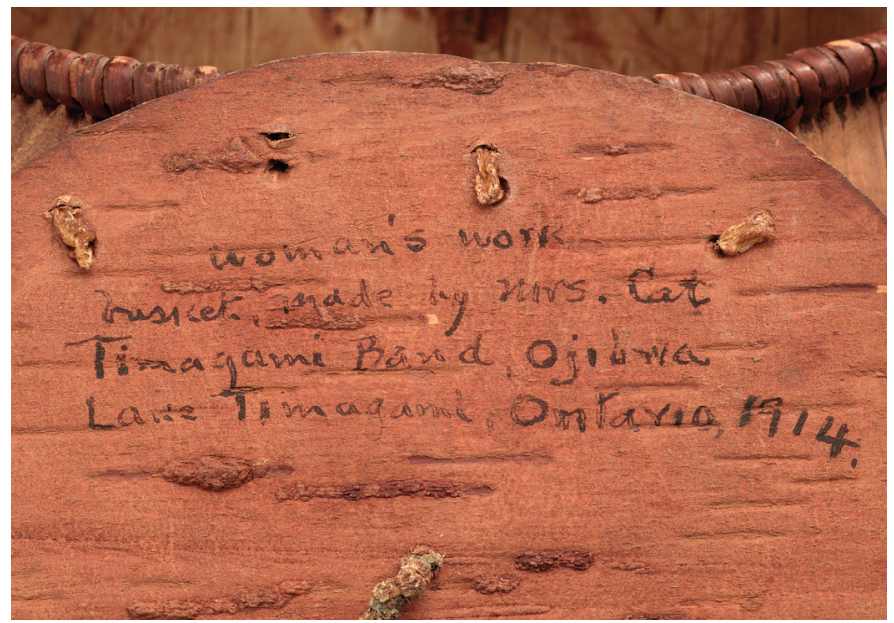

Figure 3. Detail of writing by collector Frank Speck on lid of birchbark basket. Collection of the Royal Ontario Museum 958.131 .614 ( ) ROM.

24. Deborah Doxtator, Revisions, exh. cat., Walter Philips Gallery (Banff: WPG, 1992), 25-33. 25. Reginald Ruggles Gates, "A Pedigree Study of Amerindian Crosses in Canada," The Journal of the Royal Anthropological Institute of Great Britain and Ireland, 58 (1928): plate L11.

26. David W. Penney, Native Arts of North America (Paris: Terrail, 1998), 57 . the first stage of life. In creating a protective place for her future kin, one that would be passed on from mother to daughter to grandchild, she fostered these relational ties. Although a family's creation of a tikinaagan represents the beginning of one new life, the practice of crafting and passing it down also celebrates the life of deep continuity, one that is collective, communal, and ancestral. Despite being separated by decades, or even centuries, multiple generations of Anishinaabek converge at the site of the tikinaagan, where the past comes to exist in the present. ${ }^{24}$ Indeed, the sprays of floral beadwork applied to Madeline's cradle cover reveal traces of their makers' knowledge-skills acquired and mastered over generations by the many hands of women who passed on their craft to their descendants.

Also in the Rom's collection is a small birchbark basket with a lid and hide tie that originates in the same community. | fig. 2 | Acquired by the anthropologist Frank Speck in 1914 during a visit to Bear Island in n'Daki Menan, this basket became part of his own personal collection and was later donated to ROM by his wife, Florence. Under the lid of the basket, Speck inscribed in black ink, "Women's work; Basket made by Mrs. Cat, Timagami Band, Ojibwa; Lake Temagami, Ontario, 1914." | fig. 3 | Apart from the slight variance in the spelling of the surname "Katt," this rather fortuitous and rare instance of maker identification allows for the possible attribution of this container to the hands of Madeline's great-grandmother Angele Katt, as she appears to have been commonly referred to as "Mrs. Katt" in the community and was known to craft birchbark baskets. ${ }^{25}$ What makes this one such a special and remarkable find, as Trudy Nicks, former Senior Curator in the World Cultures Department, points out, are the striking similarities between the floral design in sgraffito on the birchbark container | fig. $4 \mid$ and those of the beadwork applique on Madeline's cradleboard cover. | fig. 5 |

The sharing of designs between Anishinaabekwek kin through the teaching of skill and technique was quite common. By tracing the designs and patterns of their work on sheets of paper and birchbark, which were then cut out and used as templates, women passed them down through kinship lines, from mother to daughter, and from grandmother to granddaughter. ${ }^{26}$ The budding 
Figure 4. Detail of flower motif on birchbark basket. Collection of the Royal Ontario Museum 958.131.614 (C) ROM.
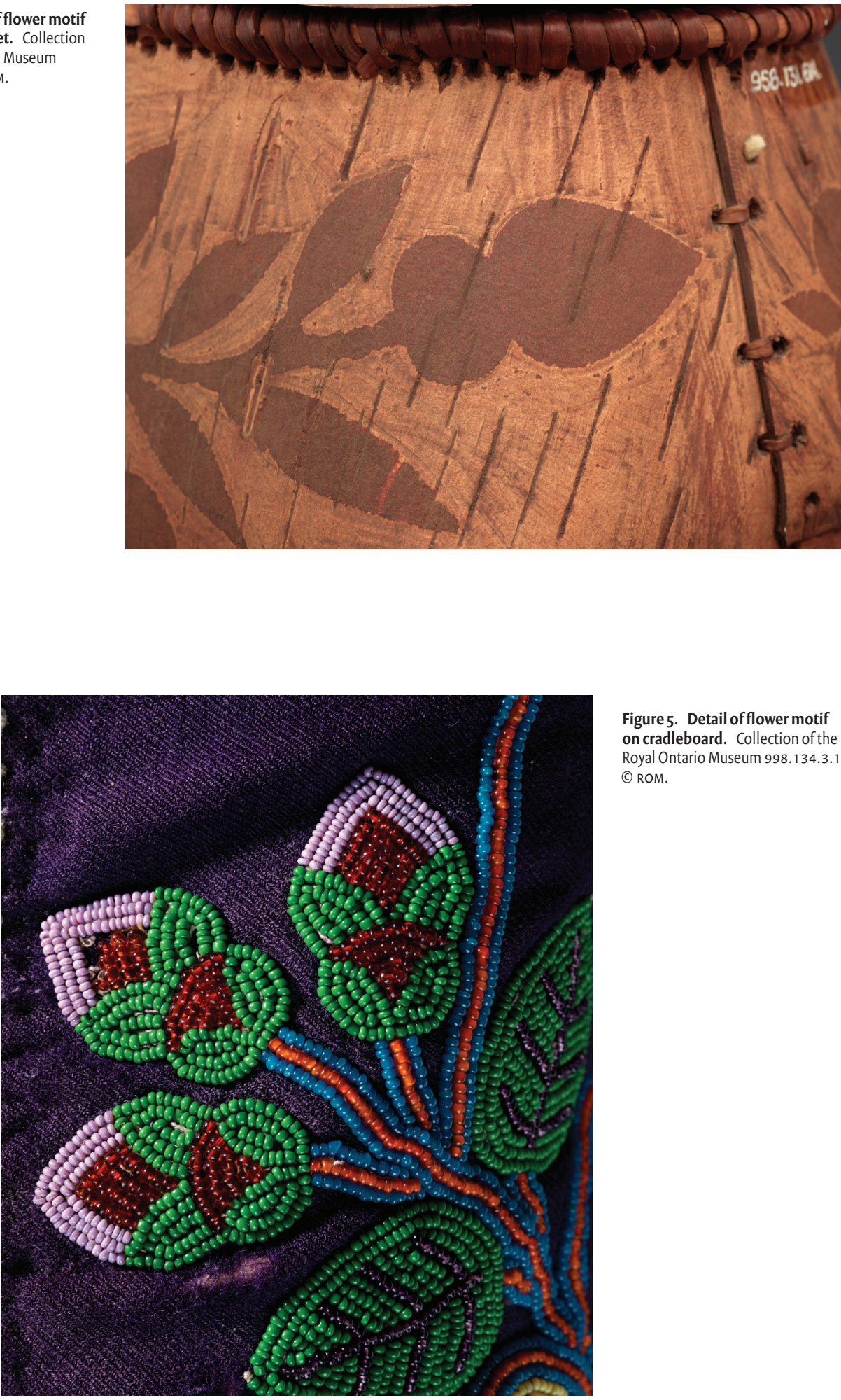

Figure 5. Detail of flower motif on cradleboard. Collection of the Royal Ontario Museum 998.134.3.1 (c) ROM. 
27. Anderson, Life Stages, 140. 28. Sherry Farrell Racette, "Encoded Knowledge: Memory and Objects in Contemporary Native American Art," in Manifestations: New Native Art Criticism, ed. Nancy Mithlo (Santa Fe, NM: Museum of Contemporary Native Arts/Rizzoli Press, 2012), 42.

29. Tom Hill and Richard Hill Sr., "Across the Generations," in Creation's Journey: Native American Identity and Belief, eds. Tom Hill and Richard W. Hill Sr. (Washington: Smithsonian Institution Press and the National Museum of the American Indian, 1994), 117. floral motifs made by Madeline's mother and great-grandmother bear a family resemblance, thus making tangible the entwined generational transmission of their makers' knowledge, one that extends across time and space.

Madeline's great-grandmother, with whom she was very close, brings this journey to the final climb of the Four Hills. Johnston asserts that the work of Elders is integral to madjimadzuin. As they tend to share very special relationships with children, who are new to this world, Elders ensure the protection of life-lines and the generational exchange between the young and old. According to Anderson, it is the grandmothers and the old ladies of communities who traditionally hold authoritative familial knowledge and responsibilities as the "ultimate guardians of kinship." 27

Madeline's tikinaagan brings this journey full circle: from the fourth hill of life, there is Angele Katt, who, in keeping with tradition, imparts knowledge to her granddaughter Elizabeth-teachings made material in the floral forms of her granddaughter's beadwork. Elizabeth, as a mother on the third hill, helps prepare her daughter Madeline, a youth at the second life stage, for parenthood by creating a cradleboard cover for her future grandchildren, the little ones who were later carried by Madeline at the beginning of their steady climb up the first hill of life. In addition to providing a warm and protective place for Madeline's babies to sleep, learn, and feel secure, this very special object is imbued with narrative power. ${ }^{28}$ It carries and holds the stirring history of a long, moving line of women whose hands retraced the forms and practices of those who came before them, thereby embodying the renewal of kinship relations through processes of making.

In Madeline's memoir, as well as in the story of her cradleboard, it is Angele Katt, the great-grandmother, who takes on the traditional role as the protector of kinship. In teaching the women of younger generations, who then care for and teach the following ones, she ensures the continuation of madjimadzuin. It seems fitting, therefore, to see the floral design as an extension of her protective presence and role as ancestral kin and ultimate guardian, which warmly wraps future generations and soothes and ensures the safety of the infants snuggly laced in the tikinaagan.

These two objects-baby carrier and birchbark basket-are family members. Although they were once separated by time, as well as the distance between their museum storage locations, they have been reunited on display at the Royal Ontario Museum, where I like to imagine them warmly visiting and catching up on old stories.

What is made manifest in this multi-generational, Anishinaabekwek family portrait is the concept of the human Milky Way. Moving life occurs through knowledge transfer. The meaning embodied in these family belongings does not arise out of their content alone, but emerges from the context of relational renewal that stirred their very making and use. In the words of Tom Hill and Richard W. Hill Sr., culture and ancestral life-lines "are not preserved in books, films or museums. They are preserved when native children learn the traditions of their people and express them in new ways" [italics added]. ${ }^{29}$ The Anishinaabe phrase mino-bimaadziwin-"living the good life"-articulates these principles of cyclical return and renewal in a way that makes change, transformation, and moving life understandable. According to Winona 
30. Winona LaDuke, Our Relations: Struggles for Land and Life (1999; repr. Chicago: Haymarket Books, 2015), 51.

31. Johnston, Ojibway Heritage, 117
LaDuke's translation, mino-bimaadziwin refers to an ongoing process of continual rebirth and reawakening. ${ }^{30}$

Just as Madeline recounted her life story in Moose to Moccasins, Angele Katt taught her granddaughter Elizabeth the importance of remembering traditions and passing them on. Visually, this renewal of tradition and generational ties is expressed through the rebirth and repetition of inherited floral designs. Basil Johnston refers to the rhythmic nature of life's Four Hills as generational seasonal shifts-they continually return, yet with each new cycle they are never fully the same. He poignantly likens this continual cycle of rebirth and renewal to the budding of flowers. Every spring, like generations of kin, new blooms arrive. Different from what came before, they maintain ancestral roots, which embody both the past and the present. Johnston envisions not loss, but an awareness of resurgent and ongoing life:

Though former modes can no longer be exercised, they live on in memory. By their very sweetness and worth they call out for living on; they deserve to be repeated in life again and again. What is good needs to be regenerated many times over. [But] to resurrect the past in forms already done, is to negate survival. The same flower does not live, die, to live again. It lives, dies, and is no more. [But] after death and passing it leaves a memory of loveliness and a promise of renewal of that beauty in another flower in another spring. ${ }^{31}$

This same kind of awareness continues to be known and lovingly shared by generations of Anishinaabekwek, from great-grandmothers to great-granddaughters, whose baby carriers and birchbark baskets continue to embody moving life. I

ACKNOWLEDGEMENTS I would like to thank the Royal Ontario Museum and Trudy Nicks for their assistance with this research. Nicks is responsible for identifying the similarities in the floral designs of the birchbark basket and cradleboard in the Rom collection that forms the basis of this essay. I am very grateful for her sound guidance and for the opportunity to further explore this material. I would also like to acknowledge the generations of Anishinaabe artists and makers of n'Daki Menan on Bear Island, Ontario. Without your vision and resilience this kind of work would not be possible. Gchi miigwech. 